\title{
LITERATUR REVIEW PENILAIAN KEKAYAAN INTELEKTUAL: BERDASARKAN BUKU INTELLECTUAL PROPERTY KARYA GORDON DAN RUSSELL
} Mochammad Fakhri Ali ${ }^{1}$, dan Doni Triono ${ }^{2}$

Politeknik Keuangan Negara STAN

E-mail : fahriali35@gmail.com, dony_triono@pknstan.ac.id

\section{INFORMASI ARTIKEL}

\section{File Diterima:}

[10 November 2021]

Revisi:

[ 15 November 2021]

\section{Diterima:}

[20 November 2021]

Kata Kunci:

Penilaian, Pendekatan penilaian, Kekayaan intelektual

\section{ABSTRAK}

This study aims to analyze the intellectual property assessment method by comparing the three approaches used in intellectual property assessment. This research was conducted by conducting a literature review based on the intellectual property book by Gordon V. Smith and Russell L. Parr. The most optimal valuation approach for intellectual property valuation is the income approach and the market approach. The income approach is the most optimal approach to assessing intellectual property because it can cover all the economic benefits provided by intellectual property but the income approach requires a fairly long process and more thoroughness to get the property value. The market approach is quite effective for valuing all types of intellectual property, but the limitations of intellectual property data sometimes limit the assessment. The cost approach is quite useful as a starting point for other approaches but cannot be used as a valuable reference because many considerations are not taken into account.

Penelitian ini bertujuan untuk menganalisis metode penilaian kekayaan intelektual dengan membandingkan tiga pendekatan yang digunakan dalam penilaian kekayaan intelektual. Penelitian ini dilakukan dengan melakukan literature review berdasarkan buku intellectual property karya Gordon V. Smith dan Russell L. Parr. Pendekatan penilaian yang paling optimal untuk dalam penilaian kekayaan intelektual adalah pendekatan pendapatan dan pendekatan pasar. Pendekatan pendapatan menjadi pendekatan yang paling optimal untuk menilai kekayaan intelektual karena dalam pendekatan pendapatan dapat mencakup semua manfaat ekonomi yang diberikan kekayaan intelektual namun pendekatan pendapatan memerlukan proses yang cukup panjang dan ketelitian yang lebih untuk mendapatkan nilai properti. Pendekatan pasar cukup efektif untuk menilai semua jenis kekayaan intelektual, namun keterbatasan data kekayaan intelektual terkadang membatasi penilaian. Pendekatan biaya cukup berguna sebagai titik awal pendekatan lain tapi tidak bisa menjadi acuan nilai karena banyak pertimbangan yang tidak diperhitungkan. 
LITERATUR REVIEW PENILAIAN KEKAYAAN INTELEKTUAL: BERDASARKAN BUKU INTELLECTUAL PROPERTY KARYA GORDON DAN RUSSELL.

Mochammad Fakhri $\mathrm{Ali}^{1}$, dan Doni Triono ${ }^{2}$

\section{PENDAHULUAN}

\subsection{Latar Belakang}

Kekayaan Intelektual adalah klasifikasi spesial dan unik dari aset tak berwujud karena pemilik Kekayaan Intelektual mendapat perlindungan hukum dari eksploitasi yang tidak sah oleh orang lain (Smith \& Parr, 2005). Istilah Kekayaan Intelektual disini mengacu pada paten, merek dagang, hak cipta, dan rahasia dagang atau pengetahuan. Dengan banyaknya potensi yang muncul dari Kekayaan Intelektual, sangat disayangkan apabila penelitian dan pengembangan yang mengangkat mengenai penilaian atas kekayaan intelektual di Indonesia masih minim. Hal ini kemungkinan disebabkan belum adanya lembaga penilaian kekayaan intelektual di Indonesia. Lembaga yang mempunyai tugas merumuskan dan melaksanaan kebijakan kekayaan intelektual yaitu Direktorat Jenderal Kekayaan Intelektual (DJKI) yang sampai saat ini belum mempunyai fokus di bidang penilaian kekayaan intelektual.

Untuk menyokong eksploitasi dari kekayaan intelektual agar optimal diperlukan adanya penilaian kekayaan intelektual. Penilaian kekayaan intelektual menurut Parr (2018) adalah proses untuk menentukan nilai moneter subjek Kekayaan Intelektual. Terdapat tiga jenis metode dalam penilaian kekayaan intelektual yaitu pendekatan biaya, pendekatan pasar, dan pendekatan pendapatan. Pendekatan biaya (Cost Approach) berusaha untuk mengukur manfaat masa depan dari kepemilikan dengan menghitung biaya pembuatan properti yang serupa. Pendekatan data pasar (Market Approach) yaitu mengukur masa manfaat dengan membandingkannya properti yang serupa di pasar. Pendekatan pendapatan (Income Approach) mengukur nilai properti dengan pertimbangan kemampuan menghasilkan pendapatan properti tersebut.

Analisis metode dalam penilaian kekayaan intelektual tidak semudah menilai aset berwujud karena masih sedikit orang yang memiliki pengetahuan tentang penilaian kekayaan intelektual. Setidaknya ada tiga tantangan dalam penilaian intelektual properti: pertama sifat informasi yang detail, kedua ketepatan dalam menentukan metode penilaian berdasarkan karakteristik aset dan ketiga ketersediaan data yang dimiliki untuk dilakukan analisis. Apabila ketiga tantangan tersebut dapat diselesaikan dengan baik, maka hasil penilaian akan semakin valid.

\subsection{Rumusan Masalah}

Untuk mengetahui dan menambah pemahaman tentang penilaian kekayaan intelektual, maka penelitian ini mencoba untuk melakukan literatur review buku Gordon V. Smith yang berjudul Intelectual
Jurnal Indonesia RICH, Vol. 2, No. 2, (2021), 28-33

Property, hal ini perlu dilakukan untuk menjawab beberapa pertanyaan rumusan masalah dalam penelitian ini, yaitu:

1. Bagaimanakah prosedur dalam penilaian kekayaan intelektual?

2. Bagaimanakah memilih pendekatan dalam penilaian kekayaan intelektual?

\subsection{Tujuan Penulisan}

Tujuan penelitian ini adalah:

1. untuk memahami prosedur dalam penilaian kekayaan intelektual.

2. untuk memilih pendekatan yang paling sesuai dalam penilaian kekayaan intelektual.

\section{LANDASAN TEORI}

\subsection{Konsep Dasar Penilaian}

Berdasarkan Kode Etik Penilaian Indonesia (KEPI) dan Standar Penilaian Indonesia (SPI) Edisi 2018 Penilaian adalah proses pekerjaan untuk memberikan estimasi dan pendapat atas nilai ekonomi suatu objek penilaian pada saat tertentu sesuai dengan SPI dan peraturan perunang-undangan yang berlaku. Untuk dapat mengestimasikan Nilai Pasar maupun selain Nilai pasar seorang penilai diharuskan untuk mengaplikasikan satu atau lebih pendekatan penilaian. Ada tiga pendekatan utama dalam melakukan penilaian yaitu Pendekatan Pasar, Pendekatan Biaya, dan Pendekatan Pendapatan. Ketiga pendekatan memiliki metode dan Teknik yang berbeda-beda, ketersediaan data yang diperlukan dan objek penilaian menentukan metode yang sesuai untuk diterapkan. Perbedaan hasil yang didapat dari berbagai metode dapat digunakan untuk mendapat estimasi nilai akhir.

Pendekatan pasar didasarkan pada harga yang dibayar sebagai indikator nilai suatu aset. Prinsip dasarnya adalah bahwa dalam kondisi tertentu penawaran dan permintaan mengarah pada keseimbangan di pasar kompetitif. Syarat dilakukannya penilaian dengan pendekatan pasar adalah informasi yang dibutuhkan untuk melakukan penilaian harus memadai, yaitu ada informasi pembanding yang sesuai dan baru terjadi di pasar. Oleh karena itu, penggunaan pendekatan ini sangat jarang digunakan untuk melakukan penilaian aset tak berwujud dan kekayaan intelektual karena kondisi yang tidak memenuhi.

Pendekatan Biaya adalah Pendekatan penilaian untuk mendapatkan indikasi nilai objek penilaian berdasarkan biaya reproduksi baru (reproduction cost new) atau biaya pengganti baru (replacement cost new), pada tanggal penilaian (cut off date) setelah dikurangi dengan penyusutan. Pendekatan ini juga didasarkan pada biaya penggantian, harga yang akan dibayar pembeli tidak akan melebihi biaya yang digunakan untuk membangun aset yang setara kecuali 
LITERATUR REVIEW PENILAIAN KEKAYAAN INTELEKTUAL: BERDASARKAN BUKU INTELLECTUAL PROPERTY KARYA GORDON DAN RUSSELL.

Mochammad Fakhri $\mathrm{Ali}^{1}$, dan Doni Triono ${ }^{2}$

ada faktor lain yang mendukung. Pada pendekatan ini aset yang sudah tidak lagi baru maka diperlukan penyesuaian karena perbedaan biaya dengan aset alternatif. Karena kebanyakan aset yang dinilai adalah aset yang tidak lagi baru maka depresiasi sangat umum untuk mengukur penurunan nilai.

Pendekatan Pendapatan (Income Capitalization Approach) adalah penilaian berdasarkan pendekatan pendapatan dilakukan dengan cara memproyeksikan seluruh pendapatan dari properti tersebut dikurangi dengan biaya operasi, selanjutnya dikapitalisasi dengan menggunakan suatu tingkat bunga pengembalian modal dan keuntungan (return on investment) (Rianto \& Jaya, 2000). Pendekatan pendapatan mempertimbangkan pendapatan yang dihasilkan aset pada masa manfaatnya karena nilai suatu investasi (properti) adalah fungsi dari aliran pendapatan yang dihasilkan, dimana semakin tinggi aliran pendapatan yang dapat dihasilkan oleh suatu properti, maka semakin tinggi pula nilai properti tersebut. Melalui pendekatan pendapatan, nilai suatu property diperoleh dari pengkapitalisasian pendapatan bersihnya (net operating income) dengan suatu tingkat kapitalisasi tertentu dengan memperhitungkan batas periode penerimaan pendapatannya.

\subsection{Penilaian Kekayaan Intelektual}

Menurut Parr (2018), penilaian kekayaan intelektual adalah proses untuk mengetahui nilai moneter dari subjek kekayaan intelektual. Kekayaan intelektual juga bisa dinilai untuk penciptaan nilai tambah yang berkelanjutan, Menurut Lopes (2011) tujuan penilaian kekayaan intelektual adalah untuk berinvestasi dalam kekayaan intelektual dan mengungkapkannya, secara internal dan eksternal, serta keputusan strategis untuk menuju penciptaan nilai tambah yang berkelanjutan, di suatu perusahaan atau bahkan di tingkat makroekonomi. Namun, benda tak berwujud itu harus diukur pada dasar yang layak sesuai kebutuhan dengan standar akuntansi utama. Beberapa tujuan atau pemicu seorang individu melakukan penilaian kekayaan intelektual yaitu seperti strategi transaksi, pelaporan keuangan, litigasi, kebangkrutan, pembiayaan, dan pajak

\section{METODE PENELITIAN}

\subsection{Metode Pengumpulan dan Sumber Data}

Penelitian ini dilakukan dengan menggunakan metode studi literatur/studi kepustakaan. Studi kepustakaan adalah penelitian yang dilakukan hanya berdasarkan atas karya tertulis, termasuk hasil penelitian baik yang telah maupun yang belum dipublikasikan (Melfianora, 2017). Metode studi literatur tidak membutuhkan studi di lapangan dan hanya dilakukan dengan mengumpulkan literatur melalui buku, internet, jurnal, karya ilmiah lainnya yang relevan dengan topik yang diangkat. Dalam penelitian ini metode studi literatur/studi kepustakaan dilakukan terhadap sebuah buku penilaian kekayaan intelektual yang ditulis oleh Gordon dan Russel. Dalam bukunya, Grodon dan Russell menjelaskan bagaimana prosedur penilaian kekayaan intelektual dengan menggunakan tiga pendekatan (biaya, pasar dan pendapatan) terhadap kekayaan intelektual berupa kepemilikan teknologi, paten, hak cipta dan merk dagang.

\section{HASIL PENELITIAN}

\subsection{Teori Penilaian Kekayaan Intelektual Gordon dan Russel}

\section{Cost Approach}

Pendekatan biaya merupakan pendekatan penilaian yang mengukur manfaat masa depan dari kepemilikan dengan mengkuantifikasi jumlah uang yang akan dibutuhkan untuk menggantikan kapabilitas layanan masa depan dari subjek kekayaan intelektual. Penentuan nilai menggunakan pendekatan biaya biasanya dimulai dengan penentuan biaya saat ini (pada tanggal penilaian) untuk mendapatkan replika properti subjek yang tidak terpakai, yang disebut biaya reproduksi baru (Cost of Reproduction New, CRN), atau dengan biaya memperoleh properti utilitas yang setara, yang disebut biaya penggantian (Cost of Replacement, COR). Adapun metode yang digunakan untuk mendapatkan perkiraan biaya dalam pendekatan biaya terdiri dari tiga metode, yaitu:

a. Tren Biaya Historis

Biaya historis memberikan indikasi biaya total yang perlu diinvestasikan untuk mereproduksi properti. Pertama, yaitu menampilkan biaya pengembangan suatu properti selama masa berjalan properti tersebut.

Gambar 1. Contoh perhitungan Tren Biaya Historis

\begin{tabular}{cccc}
\hline Year & $\begin{array}{c}\text { Original } \\
\text { Development Cos }\end{array}$ & $\begin{array}{c}\text { Transianor } 2004 \\
=1.000\end{array}$ & $\begin{array}{c}\text { Trended } \\
\text { Original Cost }\end{array}$ \\
\hline 1997 & $\$ 50,000$ & 1.954 & $\$ 7,706$ \\
1998 & 340,000 & 1.902 & 646,607 \\
1999 & 178,000 & 1.490 & 265,133 \\
2000 & 20,000 & 1.283 & 25,663 \\
2001 & 68,000 & 1.197 & 81,371 \\
2002 & 131,000 & 1.109 & 145,328 \\
2003 & 35,000 & 1.039 & 36,366 \\
2004 & 16,000 & 1.000 & 16,000 \\
& $\$ 838,000$ & & $\$ 1,314,174$ \\
\hline
\end{tabular}

Sumber: Buku Intellectual Property Gordon \& Russel

Selanjutnya, karena biaya untuk mereproduksi dinyatakan sebagai biaya historis pada tahun tersebut maka diperlukan kalkulasi yang disebut Translator untuk menyusun kembali indeks ke tahun reproduksi yang diinginkan. Setelah Translator diterapkan tren biaya asli subjek dapat dihitung. Tren biaya awal ini mewakili jumlah yang harus dikeluarkan pada tahun 
LITERATUR REVIEW PENILAIAN KEKAYAAN INTELEKTUAL: BERDASARKAN BUKU INTELLECTUAL PROPERTY KARYA GORDON DAN RUSSELL.

Mochammad Fakhri $\mathrm{Ali}^{1}$, dan Doni Triono ${ }^{2}$

tersebut untuk membuat properti dengan cara yang sama seperti digunakan di tahun-tahun sebelumnya b. Unit Cost Method

Cara lain untuk memperoleh biaya reproduksi atau biaya penggantian aset adalah memperkiraan langsung dari upaya dan biaya yang diperlukan untuk menciptakan aset serupa. Agregat dari semua biaya dapat menjadi indikasi biaya untuk mereproduksi aset

Gambar 2. Contoh perhitungan Unit Cost Method

\begin{tabular}{lrrrrr}
\hline & Hours & \multicolumn{1}{c}{ Rate } & \multicolumn{1}{c}{$\begin{array}{c}\text { Direct } \\
\text { Labor }\end{array}$} & $\begin{array}{r}\text { Overhead } \\
\text { and Profit }\end{array}$ & $\begin{array}{r}\text { Total } \\
\text { Cost }\end{array}$ \\
\hline Management specification development & 230 & $\$ 70.25$ & $\$ 16,158$ & $125 \%$ & $\$ 36,354$ \\
IT project management & 420 & 43.50 & 18,270 & $120 \%$ & 40,194 \\
Computer operations testing & 210 & 23.75 & 4,988 & $90 \%$ & 9,476 \\
Systems analysis & 1,375 & 33.85 & 46,544 & $110 \%$ & 97,742 \\
Programming \& testing & 3,350 & 31.50 & 105,525 & $110 \%$ & 221,603 \\
Documentation & 180 & 32.00 & \multicolumn{5}{c}{5,760} & $110 \%$ & $\underline{12,096}$ \\
& 5,765 & & $\$ 197,244$ & & $\$ 417,465$ \\
\hline
\end{tabular}

Sumber: Buku Intellectual Property Gordon \& Russel

\section{c. Unit of Production Method}

Perkiraan biaya lain yang umum digunakan adalah mendapatkan biaya penggantian berdasarkan biaya per unit produksi saat ini. Biaya untuk membangun jenis properti tertentu cukup seragam sehingga aturan praktis berkembang. Dengan demikian biaya dapat diperkirakan sebesar satuan per unit produksi contohnya seperti perusahaan minyak yang menghasilkan \$X per barel.

$$
F M V=C R N-P D-F O-E O
$$

$\begin{array}{ll}\text { FMV } & =\text { Fair market value } \\ C R N & =\text { Cost of replacement new } \\ P D & =\text { Physical depreciation } \\ \text { FO } & =\text { Functional obsolescence } \\ \text { EO } & =\text { Economic obsolescence }\end{array}$

Gambar 3. Diagram Alir Pendekatan Biaya

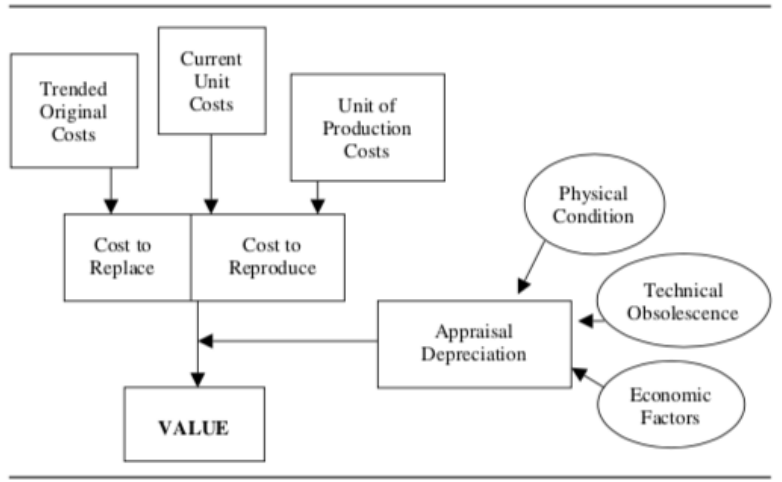

Sumber: Buku Intellectual Property Gordon \& Russel Dalam penelitian yang dilakukan oleh Rivette (2000); Chesbrough (2003); Anton dan Yao (2004) dan Thornton (2013), semuanya menggunakan pendekatan biaya dalam melakukan penilaian intelektual property.
Jurnal Indonesia RICH, Vol. 2, No. 2, (2021), 28-33

Pendekatan dengan data pasar dilakukan dengan mengindikasi nilai menggunakan pengamatan harga yang disepakati orang lain sebagai harga wajar dalam transaksi pasar terbuka dengan melibatkan aset yang identik atau sebanding dengan subjek dimana terdapat informasi harga. Untuk melakukan penilaian dengan pendekatan ini ada beberapa hal yang diperlukan yaitu:

- Pasar yang aktif dimana melibatkan aset yang diperdagangkan di public secara aktif dan ada informasi harga

- Pertukaran antara aset yang identik atau sejenis dan dapat dibandingkan

- Apabila aset tidak sepenuhnya dapat dibandingkan, terdapat variabel untuk menyesuaikan perbedaannya

Permasalahan penyesuaian seringkali ditemukan dalam melakukan penilaian dengan pendekatan pasar ini, penilai sering dihadapkan dengan kewajaran perbandingan yang diberikan dan penyesuaian yang diberikan penilai untuk meningkatkan kesamaan.

\section{a. Komparabilitas}

Transaksi yang melibatkan item kekayaan intelektual merupakan peristiwa langka. Ketika transaksi benarbenar terjadi, seringkali ketentuan pertukaran tidak diungkapkan kepada publik. Aspek tersulit dari pendekatan pasar yang diterapkan pada kekayaan intelektual adalah komparabilitas karena transaksi kekayaan intelektual merupakan hal yang langka dan kemungkinan besar tidak diungkapkan kepada publik. Bahkan informasi harga untuk pertukaran paten dan merek dagang kemungkinan besar tidak akan berpengaruh pada nilai paten dan merek dagang lain kecuali ada perbandingan.

b. Analisis usaha bisnis untuk mengindikasi nilai Pendekatan data pasar untuk mendapatkan nilai kekayaan intelektual dapat juga dilakukan dengan menentukan nilai seluruh perusahaan. Selanjutnya setelah nilai ditetapkan nilai tersebut dikurangi semua kategori aset dan menyisakan jumlah yang dianggap sebagai nilai seluruh kekayaan intelektual yang dimiliki perusahaan tersebut seperti merek dagang, hak cipta, jaringan distribusi dan teknologi kepemilikan.

Langkah pertama, indikasi nilai perusahaan perlu didapatkan terlebih dahulu. Perlu diingat bahwa nilai pada laporan keuangan perusahaan didasarkan pada prinsip akuntansi umum, nilai dari laporan keuangan kemungkinan tidak dapat mencerminkan nilai pasar dari aset.

Keseluruhan usaha dapat berisi nilai ekuitas dan hutang jangka panjang. Nilai suatu badan usaha juga sama dengan nilai aset yang ada dalam bisnis tersebut seperti modal kerja bersih, aset berwujud dan aset tidak berwujud, dimana kekayaan intelektual termasuk

\section{Market Approach}


LITERATUR REVIEW PENILAIAN KEKAYAAN INTELEKTUAL: BERDASARKAN BUKU INTELLECTUAL PROPERTY KARYA GORDON DAN RUSSELL.

Mochammad Fakhri $\mathrm{Ali}^{1}$, dan Doni Triono ${ }^{2}$

kedalam aset tidak berwujud. Rincian dari aset tersebut adalah:

- $\quad$ Modal Kerja Bersih = Aktiva Lancar - Utang Lancar

- $\quad$ Aset berwujud = Tanah + Bangunan + Mesin + Truk + peralatan kantor

- $\quad$ Aset tidak berwujud = Perangkat lunak computer + Tenaga kerja terlatih + Kontrak + Jaringan Distribusi

- $\quad$ Kekayaan Intelektual $=$ Paten + Merek Dagang + Hak Cipta + Rahasia Proses

Selanjutnya, setelah mendapat keseluruhan nilai dari badan usaha yang harus dilakukan adalah mengurangi nilai badan usaha dengan modal kerja bersih dan juga aset berwujud yang dimiliki persahaan seperti tanah, bangunan, mesin, kendaraan, dan peralatan kantor lainnya. Hasil pengurangan dari nilai tersebut menjadi indikasi nilai semua aset tak berwujud yang dimiliki perusahaan termasuk kekayaan intelektual didalamnya.

\section{Gambar 4. Contoh analisis usaha bisnis}

$\begin{array}{lr}\text { Business enterprise value } & \$ 81,775,000 \\ \text { Net working capital } & \$ 4,325,000 \\ \text { All fixed assets } & \$ 29,200,000 \\ \text { Indicated value of intangible assets and intellectual property } & \$ 48,250,000 \\ \text { Identified intangible assets } & \$ 12,000,000 \\ \text { Intellectual Property-Patented Technology } & \$ 36,250,000\end{array}$

Sumber: Buku Intellectual Property Gordon \& Russel

Langkah terakhir untuk mendapat nilai kekayaan intelektual adalah mengidentifikasi dan menilai semua jenis aset tak berwujud. Aset tak berwujud yang dimiliki sangat beragam tergantung jenis perusahaan dapat berupa kontrak, perangkat lunak komputer, tenaga kerja terlatih, dan praktek perusahaan tapabila subjek penilaian merupakan perusahaan manufaktur. Sisa dari nilai selain aset tak berwujud yang dimiliki perusahaan menjadi indikasi nilai kekayaan intelektual yang dimiliki perusahaan.

Meskipun pendekatan ini tidak memungkinkan untuk mengetahui satu jenis kekayaan intelektual secara khusus yang dimiliki perusahaan namun penerapannya masih memungkinkan memberi bantuan mengetahui kekayaan intelektual suatu perusahaan secara keseluruhan. Pendekatan ini dapat juga digunakan dengan baik untuk menilai kekayaan intelektual perusahaan multinasional dengan beragam macam bisnis.

Gambar 5. Diagram Alir Pendekatan Pasar
Jurnal Indonesia RICH, Vol. 2, No. 2, (2021), 28-33

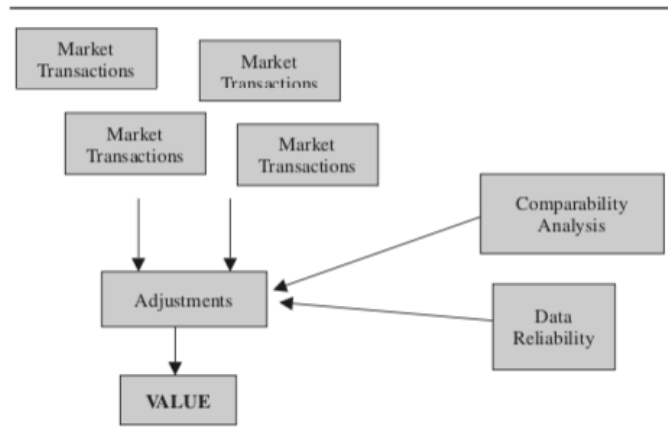

Sumber: Buku Intellectual Property Gordon \& Russel

Adapun penelitian yang menggunakan pendekatan pasar dalam melakukan penilaian kekayaan intelektual adalah Thornton (2013).

\section{Income Approach}

Penilaian dengan pendekatan pendapatan ini memiliki tujuan untuk memperkirakan nilai pasar dengan cara mendapatkan present value dari nilai manfaat ekonomis di masa depan. Ada tiga langkah yang harus dilalui untuk melakukan penilaian dengan pendekatan pendapatan tersebut yaitu mencari manfaat ekonomi yang dapat diharapkan dari eksploitasi property, menemukan pola penerimaan keuntungan ekonomi, dan menemukan asumsi tentang risiko yang terkait estimasi jumlah manfaat ekonomi tersebut.

Ada dua teknik untuk memperkirakan manfaat ekonomi dari eksploitasi kekayaan intelektual yaitu Direct (langsung) dan Indirect (tidak langsung), penggunaannya ditentukan oleh informasi yang tersedia. Teknik langsung digunakan apabila manfaat yang dihasilkan dapat diketahui secara spesifik. Apabila informasi tidak spesifik maka teknik tidak langsung dapat dilakukan dengan mengekstrak informasi spesifik dari informasi umum.

\section{a. Direct Techniques}

Kekayaan intelektual memiliki kemungkinan untuk menghasilkan keuntungan ekonomis, yaitu dengan cara meningkatkan harga jual premium secara konsisten maka dengan itu perhitungan premium pricing dapat dilakukan. Peningkatan harga tersebut bisa terjadi karena beberapa hal seperti merk dagang terkenal yang bagus dapat memberi prestise tertentu bagi pembelinya karen walaupun kualitas dan bahan sama. Selain prestise yang dihasilkan, peningkatan harga juga bisa meningkat karena adanya paten, karena produk yang dipatenkan bisa meningkatkan harganya. Namun, perlu diperhatikan bahwa manfaat ekonomis ini tidak selalu sama dengan nilai karena kemungkinan ada biaya eksploitasi untuk menghasilkan harga premium.

Teknik kedua yaitu menggunakan cost savings. Manfaat ekonomis yang diberikan kekayaan intelektual tidak selalu tentang meningkatnya pendapatan atau 
LITERATUR REVIEW PENILAIAN KEKAYAAN INTELEKTUAL: BERDASARKAN BUKU INTELLECTUAL PROPERTY KARYA GORDON DAN RUSSELL.

Mochammad Fakhri Ali $^{1}$, dan Doni Triono ${ }^{2}$

harga jual. Penghematan biaya juga dapat menjadi manfaat ekonomis yang diberikan kekayaan intelektual bahkan penghematan penjualan dapat sama menguntungkannya dengan peningkatan pendapatan penjualan. Penghematan biaya produksi juga merupakan hasil dari eksploitasi kekayaan intelektual, kekayaan intelektual yang dapat menghemat biaya produksi dapat berbentuk pengurangan atau pergantian bahan untuk produksi, peningkatan kualitas produksi, mengurangi biaya utilitas pabrik, perubahan metode produksi untuk mengurangi beban mesin, dan lain-lain.

b. Indirect Techniques

untuk mendapat manfaat ekonomi dengan teknik tidak langsung dapat menggunakan beberapa cara. Cara yang pertama yaitu pembebasan royalty Penilaian menggunakan pembebasan royalty adalah metodologi yang mendasarkan konsep jika perusahaan memiliki kekayaan intelektual maka perusahaan tersebut tidak perlu menyewanya atau membayar royalty dari kekayaan intelektual itu. Keuntungan itu dapat dimasukan ke pendapatan dari kekayaan intelektual. Perhitungan royalti ini biasa didapat dari pasar dalam industri terkait, meskipun terkadang properti subjek cukup berbeda dari data yang tersedia. Seringkali penghitungan keringanan royalti dilakukan dengan mengkapitalisasi aliran pendapatan perpetuitas dengan membagi pendapatan satu tahun setelah pajak dengan tingkat kapitalisasi.

Selanjutnya Analytical Method, Peningkatan laba yang dihasilkan oleh kekayaan intelektual dapat menunjukkan kontribusi pendapatan yang terkait dengan kekayaan intelektual yang tersedia untuk dikapitalisasi dalam pendekatan pendapatan. Dalam metode ini menganalisis margin keuntungan saja tidak cukup. Pendapatan total perusahaan yang berkaitan dengan investasi dalam aset moneter, tetap, dan pelengkap lainnya juga harus dipelajari untuk mengidentifikasi kontribusi yang diberikan oleh kekayaan intelektual.

Terakhir yaitu Analisis pendapatan dalam konteks perusahaan. Metode ini dapat tergolong produktif untuk menemukan manfaat ekonomi yang dapat dikaitkan dengan beberapa kekayaan intelektual atau aset tidak berwujud tertentu. Metode ini mirip dengan metode analisis usaha bisnis di pendekatan pasar, namun perhitungannya disini didasarkan pada pendapatan.

Langkah selanjutnya setelah mendapat nilai dari perhitungan manfaat ekonomi yaitu mengetahui waktu dan pola penerimaannya. Bagian ini penting karena present value merupakan hal yang sangat sensitif terhadap waktu dan pola penerimaan manfaat ekonomi di masa depan.
Jurnal Indonesia RICH, Vol. 2, No. 2, (2021), 28-33

Langkah terakhir untuk menilai dengan Pendekatan pendapatan sebelum menyatukan semua yaitu menentukan resiko. Resiko dinyatakan dalam bentuk persentase berupa tingkat kapitalisasi atau tingkat diskonto yang didapat di pasar tempat pembeli dan penjual melakukan transaksi. Jika penilai dapat mengetahui tentang transaksi, penilai dapat memperoleh kapitalisasi yang melekat atau tingkat diskonto yang telah disepakati pembeli. Setelah mengetahui resiko tersebut penilai bisa menemukan nilai sekarang dari manfaat ekonomis di masa depan aset.

Adapun penelitian yang menggunakan pendekatan pendapatan dalam melakukan penilaian kekayaan intelektual adalah Tkachenko et al., (2019) dan Thornton (2013).

4. Pemilihan Pendekatan Penilaian Kekayaan Intelektual

Beberapa faktor yang mempengaruhi pemilihan penggunaan pendekatan dalam penilaian kekayaan intektual antara lain: jenis properti, ketersediaan data/informasi yang ada pada masing-masing properti. Secara konsep, pendekatan biaya tidak terlalu efektif untuk menilai kekayaan intelektual. Hal ini dikarenakan penggunaan pendekatan biaya memiliki potensi besar kesalahan yang disebabkan karena manfaat ekonomi tidak diperhitungkan dalam pendekatan biaya (Lagrost et al., 2010);. Namun, penggunaan pendekatan biaya dapat sangat berguna untuk memperkirakan indikasi nilai atau sekadar sebagai titik awal untuk penilaian dengan pendekatan lain bagi semua jenis kekayaan intelektual. Pendekatan biaya dapat digunakan untuk menilai kekayaan intelektual yang pengeluarannya jelas seperti merek dagang karena biaya pengeluaran untuk membuat merek dagang seringkali tersedia.

Pendekatan pasar sangat berguna untuk mencari nilai properti yang sering ditransaksikan. Indikasi nilai kekayaan intelektual terkadang ditemukan di pasar dari berbagai kejadian seperti Transaksi Pasar, market events, dan kehilangan paten karena kelalaian pembayaran (Lopes, 2011); Indikasi nilai kekayaan intelektual juga dapat ditemukan dari analisis usaha bisnis dengan menemukan satu persatu nilai aset yang dimiliki perusahaan.

Namun, pendekatan pasar untuk menilai kekayaan intelektual menjadi sulit karena data transaksi kekayaan intelektual seringkali tidak ditemukan atau tidak dipublikasikan. Pendekatan pasar sangat efektif untuk menilai properti kekayaan intelektual berbentuk Lisensi dan Hak merek dagang karena sering ditransaksikan.

Penilaian dengan pendekatan pendapatan memiliki tiga tahapan yaitu yaitu mencari manfaat ekonomi yang dapat diharapkan dari eksploitasi properti dengan 
LITERATUR REVIEW PENILAIAN KEKAYAAN INTELEKTUAL: BERDASARKAN BUKU INTELLECTUAL PROPERTY KARYA GORDON DAN RUSSELL.

Mochammad Fakhri $\mathrm{Ali}^{1}$, dan Doni Triono ${ }^{2}$

teknik langsung atau tidak langsung, menemukan pola penerimaan keuntungan ekonomi, dan menemukan asumsi tentang risiko yang terkait estimasi jumlah manfaat ekonomi tersebut. Kesulitan mencari nilai kekayaan intelektual menggunakan pendekatan pendapatan terdapat pada manfaat ekonomi kekayaaan intelektual seringkali tidak ditemukan, ditambah umur ekonomis kekayaan intelektual sulit diperkirakan dan harus melibatkan teknisi ahli dalam menentukan umurnya (Wirtz, 2012). Penilaian dengan pendekatan pendapatan sangat cocok untuk menilai kekayaan intelektual yang memberikan manfaat ekonomi bagi kepemilikannya. Dalam prakteknya, penilaian dengan pendekatan pendapatan efektif untuk menilai Lisensi, Paten, Merek dagang, dan Hak Cipta.

\section{SIMPULAN}

Pendekatan penilaian yang paling optimal untuk mendapat nilai kekayaan intelektual adalah pendekatan pendapatan dan pendekatan pasar. Pendekatan pasar cukup efektif untuk menilai semua jenis kekayaan intelektual, namun keterbatasan data kekayaan intelektual terkadang membatasi penilaian. Pendekatan pasar menjadi salah satu pendekatan yang paling optimal untuk menilai kekayaan intelektual karena dalam pendekatan pasar dapat mencakup semua manfaat ekonomi yang diberikan kekayaan intelektual, sedangkan pendekatan pendapatan memerlukan proses yang cukup panjang dan ketelitian yang lebih untuk mendapatkan nilai properti. Pendekatan biaya sendiri cukup berguna sebagai titik awal pendekatan lain tapi tidak bisa menjadi acuan nilai karena banyak pertimbangan yang tidak diperhitungkan. Pertimbangan apakah pendekatan tersebut optimal atau tidak untuk menilai suatu jenis kekayaan intelektual itu sendiri juga bergantung kepada data yang dimiliki dan sifat kekayaan intelektual.

Kekayaan intelektual yang memiiki data pengeluaran biaya dapat dengan efektif dinilai dengan pendekatan biaya seperti merek dagang. Kekayaan intelektual yang sering ditransaksikan dapat dengan efektif dinilai dengan pendekatan pasar seperti lisensi paten dan hak merek dagang. Kekayaan intelektual yang dapat dieksploitasi dengan mendapat pendapatan dapat dengan efektif dinilai dengan pendekatan pendapatan seperti lisensi paten, merek dagang, dan hak cipta.

\section{DAFTAR PUSTAKA}

Anton, J. J., \& Yao, D. A. (2004). Little patents and big secrets: Managing intellectual property. RAND Journal of Economics, 1-22.

Chesbrough, H. (2003). The logic of open innovation: Managing intellectual property. California
Management Review, 45(3), 33-58.

Lagrost, C., Martin, D., Dubois, C., \& Quazzotti, S. (2010). Intellectual property valuation: how to approach the selection of an appropriate valuation method. Journal of Intellectual Capital.

Lopes, I. T. (2011). The boundaries of intellectual property valuation: Cost, market, income based approaches and innovation turnover. Intelektine Ekonomika, 5(1), 99-116.

Melfianora, I. (2017). Penulisan Karya IImiah dengan Studi Literatur. Pekanbaru: UPT Balai Penyuluhan Pertanian.

Parr, R. L. (2018). Intellectual property: Valuation, exploitation, and infringement damages. John Wiley \& Sons.

Rianto, R. E., \& Jaya, W. K. (2000). Pendekatan penilaian properti untuk estimasi nilai sewa tanah dan bangunan PT. KA (Persero) Daop VI guna peningkatan Pendapatan Asli Daerah (PAD) Pemerintah Daerah Istimewa Yogyakarta. Journal of Indonesian Economy and Business, 15(3), 332-338.

Rivette, K. G., \& Kline, D. (2000). Discovering new value in intellectual property. Harvard Business Review, 78(1), 54.

Smith, G. V., \& Parr, R. L. (2005). Intellectual property: Valuation, exploitation, and infringement damages. John Wiley \& Sons.

Thornton, G. (2013). Intangible assets in a business combination: Identifying and valuing intangibles under IFRS 3. Grant Thornton International Ltd.

Tkachenko, E., Rogova, E., Bodrunov, S., \& Dmitriev, N. (2019). Valuation of intellectual capital in the context of econom potential of a company. European Conference on Intangibles and Intellectual Capital, 303-XIV.

Wirtz, H. (2012). Valuation of intellectual property: A review of approaches and methods. International Journal of Business and Management, 7(9), 40. 